https://journal.unram.ac.id/index.php/ifn

VOLUME 1, NOMOR 1, JUNI 2021

https://doi.org/10.29303/jfn.v1i1.159

\title{
PENAMBAHAN PEWARNA ALAMI PADA PAKAN BUATAN TERHADAP PENINGKATAN WARNA IKAN KOI (Cyprinus carpio)
}

\section{ADDITION OF NATURAL DYES TO ARTIFICIAL FEED TO THE COLOUR IMPROVEMENT OF KOI FISH (Cyprinus carpio)}

\author{
Widi Setyogati $1^{*}$ \\ 1Departemen Pengembangan Agribisnis Perikanan, Balai Besar Pengembangan \\ Penjaminan Mutu Pendidikan Vokasi Pertanian \\ Jalan Jangari KM 14 Sukajadi, Karangtengah, Cianjur, Jawa Barat \\ *Korespondensi email: widisetyogati@gmail.com
}

\begin{abstract}
ABSTRAK
Tubuh ikan tidak memiliki kemampuan untuk mensintesis pigmen warna (karotenoid) untuk itu diperlukan penambahan pigmen warna dari luar tubuhnya untuk memenuhi kebutuhan pewarnaannya. Penggunaan karotenoid sintetis dapat memberikan dampak buruk pada lingkungan ataupun efek karsinogenenik, sehingga perlu dilakukan penelitian dan pemanfaatan penggunaan pewarna alami sebagai sumber pigmen alternatif. Penelitian ini bertujuan untuk membandingkan efektifitas sumber pigmen alami berbahan dasar hewani, nabati dan mikroorganisme terhadap peningkatan warna ikan koi. Penelitian dilaksanakan di Hatchery Budidaya Ikan Hias BBPPMPV Pertanian. Metode penelitian yang digunakan eksperimental laboratoris dengan menggunakan Rancangan Acak Lengkap (RAL) yang terdiri dari 4 perlakuan dan 3 ulangan. Perlakuan yang digunakan adalah penggunaan bahan pigmen alami pada pakan buatan yang diformulasikan untuk pakan koi, antara lain P0 (pakan komersil), P1 (tepung kulit buah naga 15\%), P2 (tepung kepala udang 10\%) dan P3 (tepung Spirulina sp 1\%). Uji coba pakan dilakukan selama 30 hari pada benih ikan koi ukuran $5-7 \mathrm{~cm}$ yang dipelihara pada kolam fiberglass dengan kepadatan 30 ekor/bak. Data yang dikumpulkan diolah dengan menggunakan analisa ANOVA dan dilanjutkan dengan uji Duncan. Hasil penelitian menunjukkan bahwa pakan perlakuan memberikan pengaruh pada presentase peningkatan warna, pertumbuhan mutlak, laju pertumbuhan spesifik dan nilai FCR, namun tidak memberikan pengaruh terhadap derajat kelangsungan hidup. Pakan perlakuan P3 memberikan pengaruh terbaik terhadap presentase peningkatan warna $(45,56 \%)$, pertumbuhan total $(2,24 \mathrm{~g})$, laju pertumbuhan spesifik $(0,75 \%$ /hari) dan nilai $\operatorname{FCR}(2,72)$ jika dibandingkan dengan perlakuan lainnya.
\end{abstract}

Kata Kunci: Ikan Koi, karotenoid, tepung kulit buah naga, tepung kepala udang, tepung Spirullina sp 


\section{ABSTRACT}

The body of the fish does not have the ability to synthesize color pigments (carotenoids) for it is necessary to add color pigments from outside its body to meet its coloring needs. The use of synthetic carotenoids can adversely affect the environment or carcinogenenic effects, so research and utilization of natural dyes as an alternative source of pigments is needed. This study aims to compare the effectiveness of natural pigment sources made from animals, vegetables and microorganisms against the increasing color of koi fish. The research was conducted at hatchery ornamental fish cultivation BBPPMPV Agriculture. The research method used experimental laboratory using a Complete Randomlzed Design (RAL) consisting of 4 treatments and 3 replays. The treatment used is the use of natural pigments in artificial feed formulated for koi feed, among others P0 (commercial feed), P1 (dragon fruit skin flour 15\%), P2 (shrimp head flour 10\%) and P3 (Spirulina flour sp 1\%). Feed trials were conducted for 30 days on koi fish seeds size $5-7 \mathrm{~cm}$ maintained in fiberglass ponds with a density of 30 heads / tub. The data collected was processed using ANOVA analysis and continued with Duncan test. The results showed that feed treatment influenced the percentage of color increase, absolute growth, specific growth rate and FCR value, but did not affect the degree of survival. P3 treatment feed gives the best effect on the percentage of color increase $(45.56 \%)$, total growth $(2.24$ g), specific growth rate $(0.75 \% /$ day $)$ and FCR value (2.72) when compared to other treatments.

Key words: koi fish, carotenoids, dragon fruit skin meal, shrimp head meal, Spirullina sp meal

\section{PENDAHULUAN}

Warna merupakan salah satu parameter dalam penentuan nilai ikan hias. Semakin cerah warna suatu jenis ikan, maka semakin tinggi nilainya. Faktor makanan memiliki pengaruh dalam pembentukan warna ikan hias, oleh sebab itu perlu diberikan pakan yang dapat mendukung penampakan warna tersebut (Nazhira S, 2017). Hal ini juga dikuatkan oleh pendapat (Ahilan B, 2013) yang menyatakan bahwa karotenoid merupakan pigmen utama pada kulit ikan hias, tetapi ikan tidak mampu mensintetis karotenoid. Dengan demikian kebutuhan karotenoid harus diberikan melalui pakan.

Pakan ikan hias yang mengandung pigmen tambahan relatif mahal harganya jika dibandingkan dengan pakan ikan konsumsi. Hal ini disebabkan karena pigmen yang digunakan sebagai tambahan bahan baku pakan merupakan pigmen sintetis yang dapat memberikan perubahan warna secara instan namun bila terakumulasi secara berlebihan berbahaya bagi tubuh ikan. Penggunaan karotenoid sintetis dapat memberikan dampak buruk seperti kerusakan lingkungan dan efek karsinogenik selain harganya yang juga mahal (Gupta et al., 2007). Hal ini yang menyebabkan perlu dilakukan penelitian dan pemanfaatan penggunaan pewarna alami sebagai sumber pigmen alternatif.

Karotenoid merupakan pigmen yang larut dalam lemak (Mortensen, 2006) dikenal juga sebagai lipochrome, saat ini sudah ditemukan lebih dari 650 jenis karotenoid di alam. Peran karotenoid dalam bidang akuakultur sangat luas (Meyer \& Latscha 1997 dalam (Sukarman, 2017), di antaranya adalah berperan dalam 
keseimbangan ekosistem hewan-hewan air, mempunyai peran yang luas dalam fungsi biologis : pro-vitamin $A$, antioksidan, penting dalam proses perkembangan embrio dan larva, memproteksi ikan dari kerusakan karena perubahan kondisi lingkungan yang ekstrim, berperan dalam proses reproduksi dan mampu meningkatkan sistem imun tubuh ikan. Peran lain yang tidak kalah penting adalah sebagai agen pigmentasi untuk kepuasan pelanggan baik pada udang, ikan konsumsi maupun ikan hias.

Beberapa bahan nabati yang telah diujikan pada ikan hias antara lain tepung bunga marigold (Tagetes erecta) terhadap peningkatan kecerahan warna ikan rainbow (Noviantoro et al., 2017). Tepung buah labu kuning mampu meningkatkan kecerahan dan pertumbuhan ikan badut (Sartikawati et al., 2020). Ekstrak ubi jalar pada peningkatan performa warna tubuh, pertumbuhan dan kelulushidupan ikan rainbow (Yaeni et al., 2017). Paprika merah (Capsicum annuum) terhadap peningkatan keserahan warna pada ikan Koi (Putriana et al, 2015). Serta tepung kulit buah naga yang mampu meningkatkan warna ikan mas koi (Kalidupa et al., 2018). Pemanfaatan bahan hewani terhadap peningkatan warna pada ikan hias antara lain penambahan tepung rebon pada pakan buatan untuk peningkatan kualitas warna dan pertumbuhan ikan Albino Tiger Barb (Addini et al., 2017). Penggunaan tepung kepala udang dalam pakan terhadap peningkatan kualitas warna ikan ikan rainbow (Subamia et al., 2013). Penggunaan tepung magot pada penampilan warna dan pertumbuhan benih ikan rainbow kurumoi (Prayogo et al., 2012). Demikian juga dengan pemanfaatan mikroalga sebagai sumber pigmen untuk ikan hias antara lain Tepung Spirullina platensispada yang diujikan pada peningkatan warna ikan mas koki (Utomo et al., 2006). Mikroalga air tawar Haematococcus pluvialis dapat digunakan sebagai sumber pigmen untuk ikan hias yang berwarna kuning, merah, atau warna lain (Gupta et al., 2007). Malini et al., (2018) juga melakukan penelitian yang menunjukkan penambahan tepung Spirulina fusiformis berpengaruh nyata terhadap peningkatan warna ikan koi. Mengacu pada penelitian-penelitian yang telah dilakukan sebelumnya maka penelitian ini bertujuan untuk membandingkan efektifitas bahan pewarna alami berbahan dasar hewani, nabati dan mikroalga terhadap peningkatan warna ikan koi (Ciprinus carpio).

\section{METODE PENELITIAN}

Penelitian dilaksanakan di Hatchery Ikan Hias dan Laboratorium Kualitas Air Departemen Agribisnis Perikanan, BBPPMPV Pertanian Cianjur Jawa Barat. Penelitian dilaksanakan selama 4 bulan mulai bulan November 2020 sampai dengan Februari 2021. Penelitian ini menggunakan pendekatan kuantitatif dengan model eksperimental laboratoris menggunakan Rancangan Acak Lengkap (RAL) dengan 4 perlakuan dan 3 kali ulangan. Perlakuan penambahan pakan buatan dengan pigmen alami berbahan nabati, hewani, dan mikroalga, mengacu pada dosis optimal penelitian sebelumnya yaitu sebagai berikut:

P0 : Pakan komersil ikan hias (kontrol)

P1 : Pakan buatan dengan penambahan tepung kulit buah naga 15\% (Kalidupa et al., 2018)

P2 : Pakan buatan dengan penambahan tepung kepala udang 10\% (Subamia et al., 2013)

P3 : Pakan buatan dengan penambahan tepung Spirullina sp 1\% (Malini et al., 2018) Populasi pada penelitian ini adalah benih ikan koi yang diujikan dengan ukuran

5-7 cm/ekor dengan padat tebar 30 ekor yang dipelihara pada kolam berukuran 
fiberglass dengan diameter $100 \mathrm{~cm}$ dan ketinggian air $30 \mathrm{~cm}$ dilengkapi dengan aerasi. Ikan uji akan diadaptasikan terlebih dahulu terhadap pakan perlakuan selama kurang lebih 1 minggu.

Pengumpulan data penelitian yang akan dilakukan terdiri dari beberapa tahapan, antara lain:

\section{Persiapan pakan uji}

Penelitian diawali dengan tahap persiapan pakan terlebih dahulu. Perhitungan formulasi pakan untuk memperoleh kebutuhan bahan baku yang dibutuhkan dalam pembuatan pakan untuk penelitian. Setelah diperoleh formulasi pakan uji, dilakukan pengeringan dan penepungan kulit buah naga, penepungan kepala udang, persiapan tepung spirulina beserta bahan baku lainnya. Pembuatan pakan uji dilakukan secara bertahap, ukuran pakan disesuaikan dengan bukaan mulut ikan yang akan diujikan. Setelah pakan uji selesai dibuat dilakukan uji proksimat pakan untuk mengetahui kandungan gizi pakan yang akan diujikan. Hasil uji proksimat pakan uji yang digunakan pada penelitian dapat dilihat pada Tabel 1.

Tabel 1. Kandungan gizi pakan uji hasil analisa proksimat

\begin{tabular}{|l|c|c|c|c|}
\hline \multirow{2}{*}{ Kandungan Pakan } & \multicolumn{4}{|c|}{ Perlakuan } \\
\cline { 2 - 5 } Kadar Protein (\%) & P0 & P1 & P2 & P3 \\
Kadar Air (\%) & 30 & 28,11 & 30,43 & 29,82 \\
Kadar Abu (\%) & 12 & 12,94 & 9,82 & 10,35 \\
Kadar Lemak (\%) & 12 & 10,41 & 13,54 & 11,10 \\
Kadar Serat (\%) & 3 & 6,68 & 5,82 & 7,73 \\
Kadar Pati (\%) & 4 & 7,25 & 6,22 & 6,64 \\
\hline
\end{tabular}

Keterangan : Pakan Komersil Takari produksi PT. Central Windu Sejati

\section{Pemeliharaan ikan uji}

Kegiatan pemeliharaan ikan uji akan dilaksnakan selama 30 hari. Pada awal pemeliharaan ikan uji akan diukur terlebih dahulu jumlah, berat dan warna tubuh ikan awal untuk memperoleh data awal penelitian. Selama masa penelitian ikan uji diberi pakan perlakuan selama 3 kali sehari yaitu pagi, siang dan sore hari secara at satiation sebanyak $5 \%$ dari bobot biomassa per hari.

\section{Pengumpulan dan pengolahan data}

Pada akhir penelitian ikan disampel kembali untuk diamati perkembangan yang diperoleh baik jumlah, berat ataupun warna tubuh selama penelitian. Parameter yang diamati meliputi presentase peningkatan warna dengan mengamati perubahan warna pada ikan koi pada tubuh bagian punggung. Perubahan warna ikan mas koki diidentifikasi dengan menggunakan standar warna Taco Color Finder (TCF) yang telah dibuat skala 1-10. Pengamatan dilakukan oleh tiga panelis yang tidak buta warna. Pengamatan pertumbuhan mutlak, laju pertumbuhan spesifik, feed convention ratio dan survival rate juga dilakukan sebagai data pendukung kualitas pakan. Dari data yang telah diperoleh akan dilakukan analisis data menggunakan analisys of variance (ANOVA) dilanjutkan dengan Uji Duncan untuk mengetahui beda nyata (significancy) pada setiap perlakuan yang diberikan, sehingga dapat diperoleh rekomendasi pakan terbaik. 


\section{HASIL}

Penggunaan sumber pigmen alami seperti tepung kulit buah naga, tepung kepala udang dan tepung spirulina pada pakan uji mampu meningkatkan warna pada ikan koi. Setelah 30 hari masa pemeliharaan dengan menggunakan pakan uji diperoleh hasil yang signifikan terhadap parameter-parameter pengamatan penelitian. Hasil pengamatan setelah penelitian dapat dilihat pada tabel 2.

Tabel 2. Hasil pengamatan parameter-parameter uji

\begin{tabular}{lcccc}
\hline & \multicolumn{4}{c}{ Perlakuan } \\
\cline { 2 - 5 } Parameter & P 0 & P1 & P2 & P3 \\
\hline Bobot Awal (g) & $3,49 \pm 0,16$ & $3,69 \pm 0,19$ & $3,75 \pm 0,36$ & $3,34 \pm 0,41$ \\
Bobot Akhir (g) & $4,59 \pm 0,29$ & $5,02 \pm 0,14$ & $5,46 \pm 0,21$ & $5,57 \pm 0,17$ \\
Presentase Peningkatan Warna (\%) & $31,80 \pm 3,02^{\mathrm{ab}}$ & $31,41 \pm 3,19^{\mathrm{a}}$ & $44,69 \pm 2,89^{\mathrm{c}}$ & $45,56 \pm 3,88^{\mathrm{c}}$ \\
Pertumbuhan mutlak (g) & $1,10 \pm 0,21^{\mathrm{a}}$ & $1,32 \pm 0,10^{\mathrm{ab}}$ & $1,71 \pm 0,30^{\mathrm{bc}}$ & $2,24 \pm 0,49^{\mathrm{c}}$ \\
Laju Pertumbuhan Harian (\%/hari) & $0,40 \pm 0,07^{\mathrm{a}}$ & $0,44 \pm 0,05^{\mathrm{ab}}$ & $0,55 \pm 0,12^{\mathrm{bc}}$ & $0,75 \pm 0,20^{\mathrm{c}}$ \\
Feed Convention Ratio & $5,41 \pm 0,94^{\mathrm{bc}}$ & $4,71 \pm 0,66^{\mathrm{bc}}$ & $3,81 \pm 0,99^{\mathrm{ab}}$ & $2,72 \pm 0,97^{\mathrm{a}}$ \\
Survival Rate (\%) & $81,11 \pm 1,92^{\mathrm{a}}$ & $83,33 \pm 3,33^{\mathrm{a}}$ & $84,44 \pm 1,92^{\mathrm{a}}$ & $82,86 \pm 5,97^{\mathrm{a}}$ \\
\hline
\end{tabular}

Keterangan : angka yang memiliki huruf yang sama menunjukkan tidak berbeda nyata pada setiap perlakuan

Secara umum semua pakan perlakuan memberikan dampak yang baik pada ikan uji. Perlakuan yang menunjukkan hasil optimal adalah perlakuan P3 (Tepung Spirulina sp $1 \%$ ) diikuti dengan P2 (Tepung kepala udang 10\%). Perlakuan tersebut menunjukkan perbedaan yang nyata pada peningkatan warna, pertumbuhan mutlak, laju pertumbuhan harian, dan feed convention ratio. jika dibandingkan dengan perlakuan P0 (Pakan komersil) dan P1 (Tepung kulit buah naga 15\%).

\section{PEMBAHASAN}

\section{Peningkatan Warna}

Pakan perlakuan yang diberikan pada ikan selama masa pemeliharaan 30 hari memberikan dampak terhadap peningkatan warna ikan. Peningkatan warna ikan koi dapat dilihat pada gambar 1 dibawah ini.

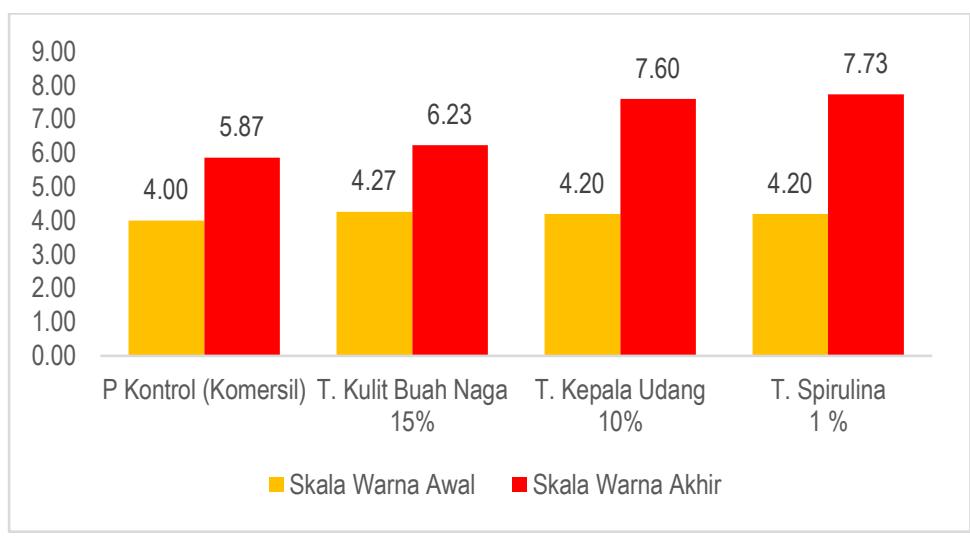


Gambar 1. Grafik peningkatan warna ikan koi

Pada grafik diatas nampak bahwa semua pakan yang diberikan pada ikan uji mampu meningkatkan warna ikan koi, hal ini membuktikan bahwa pemberian pakan uji yang mengandung karoten alami maupun pakan kontrol dapat dimetabolisme dan disimpan oleh sel pigmen ikan koi. Kandungan karoten pada tubuh terus meningkat seiring pertumbuhan dan konsumsi pakan. Pada perhitungan persentase peningkatan warna ikan koi tertinggi ditunjukkan pada perlakuan P3 (tepung spirulina 1\%) pada pakan yaitu mencapai $45,56 \%$, namun hal ini tidak berbeda nyata dengan pakan perlakuan P2 (tepung kepala udang 10\%) yang juga meningkat sebanyak 44,69\%. Presentase peningkatan warna ikan koi sesudah pemberian pakan uji pada perlakuan P0 (pakan komersil) dan P1 (tepung kulit buah naga 15\%) juga meningkat seiring dengan pertumbuhan ikan koi, kedua perlakuan tersebut tidak berbeda nyata dan nilainya relatif lebih rendah jika dibandingkan dengan perlakuan P2 dan P3. Gambar pengukuran skala warna pada akhir penelitian dapat dilihat pada gambar 2 dibawah ini.

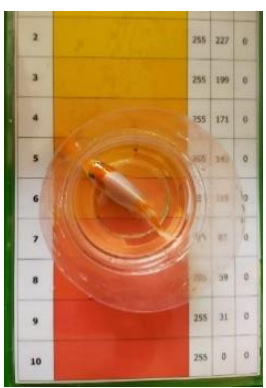

Perlakuan P0

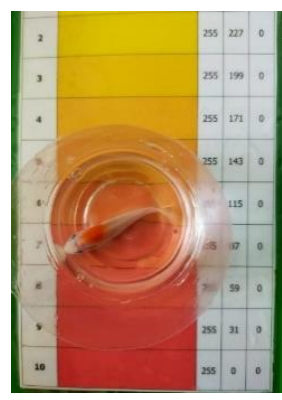

Perlakuan P1

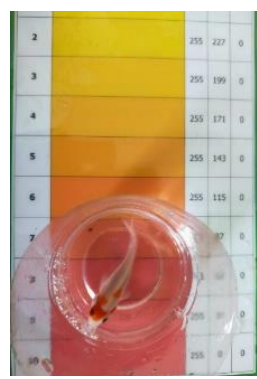

Perlakuan P2

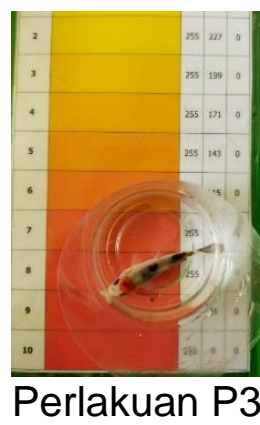

Perlakuan P3

Gambar 2. Pengukuran skala warna ikan koi

Karotenoid pada tepung spirulina dan tepung kepala udang yang terkandung pada pakan perlakuan dapat meningkatkan warna ikan koi secara signifikan. Tongsiri et al., (2010) menyatakan bahwa Spirulina sp merupakan alga hijau biru yang kaya protein, vitamin, mineral dan nutrien lainnya. S. platensis memiliki kandungan phycocyanin, chlorophyll-a dan karoten. Karoten tersusun atas xantofil (37\%), Bcarotene (28\%) dan zeaxanthin (17\%). Sedangkan Hertrampf dan Pascual (1999) menyatakan bahwa tepung udang rebon mengandung karotenoid jenis astaxantin, yang diketahui memiliki warna merah muda (pink).

Ikan Koi merupakan ikan omnivora yang cenderung herbivora memiliki kemampuan untuk menyimpan karoten yang ada pada makanannya, melalui proses metabolisme lemak untuk kemudian disimpan pada sel pigmen yang tersimpan dibawah kulitnya. Pernyataan tersebut sesuai dengan Indarti dkk. (2012), yang menyatakan bahwa kandungan karotenoid dalam tepung $S$. platensis dapat meningkatkan jumlah sel kromatofor pada ikan. Sel kromatofor adalah sel pigmen memiliki bentuk yang bulat dan terletak menyebar di seluruh lapisan sel epidermis kulit ikan. Butiran dermis yang tersebar di dalam sel menyebabkan sel menyerap sempurna sehingga terjadi peningkatan warna sisik yang menyebabkan warna sisik pada ikan menjadi lebih jelas dan terang.

Kandungan zeaxantin pada Spirulina sp dan astaxantin pada tepung kepala udang membuat kemampuan ikan koi dalam menyimpan karoten pada sel kromatofor. Hal ini juga didukung oleh pendapat Latscha (1990) yang menyatakan bahwa kelompok ikan yang bersifat herbivora, seperti ikan mas. Kelompok ini mampu menyimpan $\beta$-karoten, lutein, zeaxantin, cantaxantin dalam tubuhnya tanpa 
mengubah struktur awalnya dan mampu mengkonversi menjadi astaxantin. Hal ini juga didukung dengan pendapat O'Sullivan et al., (2011) mengungkapkan bahwa mikroalga yang mengandung pigmen karotenoid dan nutrien yang cukup tinggi diantaranya adalah Chlorella dan Spirulina. Spirulina adalah salah satu alga jenis hijau biru yang kandungan karotenoid utamanya berupa zeaxantin.

Penambahan tepung spirulina $1 \%$ pada pakan uji terbukti cukup memberikan peningkatan warna pada benih koi yang dipelihara. Hal ini disebabkan karena sel pigmen pada benih koi masih terus berkebang seiring dengan pertumbuhannya. Pigmentasi pada benih koi relatif belum stabil baik pola warna ataupun kecerahan warnanya. Hal ini dipengaruhi tidak hanya oleh genetik, namun juga kualitas pakan dan kualitas air media hidupnya yang juga turut berperan dalam pembentukan warna ikan koi. Utomo et al., (2006) pada penelitiannya juga menyatakan bahwa kebutuhan karotenoid pada ikan muda relatif lebih sedikit karena perubahan warna tubuhnya belum tetap. Kadar yang lebih rendah sudah mencukupi kebutuhan ikan koi akan karotenoid dalam spirulina.

\section{Pertumbuhan Mutlak}

Pertumbuhan mutlak terbaik ditunjukkan pada perlakuan P3 (penambahan tepung Spirulina sebanyak $1 \%$ ) hal ini disebabkan karena Spirulina memiliki kandungan protein yang tinggi dan dapat dimanfaatkan dengan baik oleh ikan koi. Spirulina sp memiliki kandungan protein mencapai 65\%, dan kaya akan kandungan asam amino yang dapat mendukung pertumbuhan ikan uji Halver and Hardy (2002).

Spirulina sp memiliki kandungan pigmen biru yang umum disebut phycocyanin yang dapat meningkatkan kekebalan tubuh. Weil (2000) dalam Arlyza (2005) meyatakan bahwa phycocyanin merupakan pigmen biru yang secara structural mirip dengan beta-karoten, yang diketahui mampu meningkatkan aksi system kekebalan dan berperan aktif melindungi tubuh dari penyakit. Peran karotenoid lainnya pada ikan adalah kemampuannya dalam memacu sistem imun ikan dan meningkatkan status kesehatannya. Beberapa penelitian telah mengungkapkan bahwa respons imun ikan dapat ditingkatkan dengan pemberian pakan yang mengandung karotenoid (Anbazahan et al. 2014; Ibrahim dan Banaee 2014 dalam Meilisza. 2018). Hal ini juga yang menyebabkan ikan koi yang diberi perlakuan dengan spirulina $1 \%$ dapat tumbuh dengan baik.

\section{Laju Pertumbuhan Spesifik (SGR)}

Laju pertubuhan spesifik atau dikenal juga dengan laju pertumbuhan harian berbanding lurus dengan pertumbuhan mutlak. Laju pertumbuhan harian merupakan pertumbuhan ikan uji setiap harinya, hal ini juga menunjukkan bahwa pemberian pakan uji memberikan pertumbuhan pada ikan uji. Tinggi rendahnya nilai laju pertumbuhan harian sangat berhubungan dengan pertambahan berat tubuh ikan yang berasal dari pakan yang dikonsumsi. Pertambahan berat merupakan salah satu indikator pertumbuhan pada ikan. Protein pakan merupakan zat pembangun yang sangat berperan pada proses pertumbuhan. Dengan mengetahui laju pertumbuhan spesifik dapat juga menunjukkan bahwa kandungan protein pada pakan dapat dimanfaatkan dengan baik oleh ikan untuk pertumbuhan.

Penambahan tepung spirulina dan tepung kepala udang pada pakan dapat memberikan laju pertumbuhan spesifik yang optimal, hal ini menunjukkan bahwa spirulina dan tepung kepala udang dapat memiliki kandungan protein dan unsur asam amino yang dimanfaatkan dengan baik untuk pertumbuhan ikan koi. Halver dan Hardy 
(2002) menyatakan bahwa Spirulina sp memiliki kandungan protein kasar mencapai $65 \%$, dengan kandungan asam amino Iso 3,90, Leu 5,20, Lys 3,00, Met 0,91, Phe 3,25, Thr 3,00, Try 0,91 dan Val 4,22. Sedangkan limbah udang memiliki kadar protein kasar mencapai 44,2\% dengan kandungan asam amino Arg 2,70, His 1,07, Iso 1,86, Leu 2,98, Lys 2,41, Met 0,91, Cys 0,66, Phe 1,76, Tyr 1,47, Thr 1,58, Try 0,40 dan Val 2,03. Kandungan asam amino pada tepung kepala udang atau limbah udang lebih lengkap jika dibandingkan dengan Spirulina $\mathrm{sp}$, namun spirulina $\mathrm{sp}$ memiliki dosis yang lebih tinggi. Kelengkapan kandungan dan jumlah asam amino inilah yang diduga dapat mendukung pertumbuhan ikan koi dengan optimal sesuai dengan hasil yang diperoleh pada penelitian, dimana penggunaan tepung kepala udang dan tepung spirulina menunjukkan laju pertumbuhan harian yang optimal.

\section{Feed Convention Ratio (FCR)}

Nilai konversi pakan berbanding terbalik dengan nilai pertumbuhan, semakin tinggi nilai pertumbuhan maka semakin rendah nilai konversi pakan, hal ini menunjukkan bahwa pakan yang habis dikonsumsi oleh ikan dapat dimanfaatkan dengan baik oleh ikan uji melalui proses metabolismenya sehingga dapat mendukung pertumbuhan ikan. Konversi pakan merupakan perbandingan antara jumlah pakan yang diberikan dengan jumlah bobot ikan yang dihasilkan. Semakin kecil nilai konversi pakan berarti tingkat efisiensi pemanfaatan pakan lebih baik, sebaliknya apabila konversi pakan besar, maka tingkat efisiensi pemanfaatan pakan kurang baik. Dengan demikian konversi pakan menggambarkan tingkat efisiensi pemanfaatan pakan yang dicapai. Nilai konversi pakan menunjukkan seberapa besar pakan yang dikonsumsi menjadi biomassa tubuh ikan.

Dari hasil penelitian yang diperoleh pakan yang dapat dimanfaatkan dengan baik oleh ikan uji adalah pakan dengan tambahan tepung spirulina $(2,72)$ diikuti dengan tepung kepala udang $(3,81)$, tepung kulit buah naga $(4,71)$ dan terakhir pakan kontrol $(5,41)$. Nilai konversi pakan berdasarkan analisa ANOVA menunjukkan bahwa perlakuan yang berbeda memberikan pengaruh terhadap nilai FCR dimana perlakuan dengan pakan tepung spirulina dan tepung kepala udang tidak berbeda nyata.

Menurut Mudjiman (2011), konversi makanan pada ikan berkisar antara 1,5-8, berarti nilai konversi pakan pada semua perlakuan dapat dikatakan baik, karena secara umum masih dalam kisaran. Dengan demikian pakan buatan yang diberikan mempunyai kualitas yang cukup baik, karena pakan yang diberikan benar-benar dapat dimanfaatkan oleh ikan untuk pertumbuhan bobot yang maksimal.

\section{Survival Rate}

Berdasarkan hasil analisa statistik dengan ANOVA dan diuji lanjut dengan uji Duncan nilai derajat kelangsungan hidup disetiap perlakuan tidak berbeda nyata. Hal ini menunjukkan bahwa perlakuan pemberian pakan yang berbeda tidak mempengaruhi derajat kelangsungan hidup ikan uji selama penelitian. Nilai derajat kelangsungan hidup sangat berhubungan dengan nilai kualitas air media pemeliharaan. Kisaran kualitas air selama penelitian dapat dilihat pada Tabel 3. 
Tabel 3. Kisaran kualitas air selama penelitian

\begin{tabular}{lcccc}
\hline \multirow{2}{*}{ Parameter } & \multicolumn{4}{c}{ Perlakuan } \\
\cline { 2 - 5 } & P0 & \multicolumn{1}{c}{ P1 } & P2 & \multicolumn{1}{c}{ P3 } \\
\hline Suhu $\left({ }^{\circ} \mathbf{C}\right)$ & $24-26,3$ & $24,3-26,6$ & $24,1-26,4$ & $24,2-26,5$ \\
Oksigen Terlarut & $4,3-7,3$ & $4,5-7,6$ & $4,4-7,5$ & $4,6-7,6$ \\
(mg/l) & $7,4-8,2$ & $7,5-8,2$ & $7,3-8,2$ & $7,4-8,2$ \\
pH & & &
\end{tabular}

Kegiatan penelitian yang dilakukan di dalam hatchery menunjukkan nilai kisaran suhu yang berkisar antara $24-26,5^{\circ} \mathrm{C}$, kisaran suhu tersebut masih dapat ditolerir oleh ikan koi. Papilon dan Efendi (2017) menyatakan bahwa ikan koi merupakan jenis ikan yang kuat. Koi mampu bertahan hidup pada kondisi air dengan kisaran suhu 20$28^{\circ} \mathrm{C}$. namun perubahan suhu yang drastis akan menimbulkan efek yang tidak baik untuk koi, dapat menyebabkan stres bahkan kematian pada ikan koi. Peningkatan suhu akan menurunkan konsentrasi DO (dissolve oxygen), meningkatkan laju metabolisme dan konsumsi oksigen ikan.

Menurut Lesmana (2002), pada suhu lingkungan turun mendadak akan terjadi degradasi eritrosit sehingga proses respirasi (pernafasan atau pengambilan oksigen) terganggu. Sebaliknya, pada suhu yang meningkat tinggi akan menyebabkan ikan bergerak aktif, tidak mau berhenti makan, dan metabolisme cepat meningkat sehingga kotoran menjadi lebih banyak. Kotoran yang banyak akan menyebabkan kualitas air disekitarnya menjadi buruk. Sementara kebutuhan oksigen meningkat, tetapi ketersediaan oksigen air buruk sehingga ikan akan kekurangan oksigen dalam darah. Akibatnya ikan menjadi stres dan terganggu keseimbangannya.

Kisaran oksigen terlarut pada media pemeliharaan selama pemeliharaan berkisar antara 4,3 - 7,6, fluktuasi oksigen terlarut sangat dipengaruhi oleh fluktuasi suhu. Papilon dan Efendi (2017) menyatakan bahwa kisaran oksigen terlarut yang optimal untuk pertumbuhan koi adalah $>5 \mathrm{mg} / \mathrm{l}$. Fluktuasi perubahan oksigen terlarut pada media sangat mempengaruhi kehidupan benih koi yang dipelihara, hal inilah yang menyebabkan kematian pada ikan koi.

Afrianto dan Liviawaty (1992) menyatakan bahwa derajat keasaman $(\mathrm{pH})$ untuk kehidupan benih ikan koi berkisar antara 7,5 - 8,5. Hasil pengukuran $\mathrm{pH}$ media pemeliharaan koi yang dilakukan di hatchery berkisar antara 7,3-8,2. Nilai ini masih termasuk ke dalam kisaran optimal untuk pemeliharaan ikan koi.

Pemeliharaan ikan koi dalam hatchery dan kondisi cuaca yang sering hujan pada malam hari dan panas pada siang hari menyebabkan tidak stabilnya kondisi kualitas air pemeliharaan ikan koi selama pemeliharaan. Perubahan kualitas air yang fluktuatif menyebabkan ikan stres, mengurangi nafsu makan hingga akhirnya menyebabkan kematian pada ikan uji.

\section{KESIMPULAN}

Penambahan pewarna alami yang bersumber dari bahan nabati, hewani dan mikroalga memberikan pengaruh pada presentase peningkatan warna, pertumbuhan mutlak, laju pertumbuhan spesifik dan nilai FCR, namun tidak memberikan pengaruh terhadap derajat kelangsungan hidup. Pakan perlakuan P3 (Tepung Spirulia sp 1\%) memberikan pengaruh terbaik terhadap presentase peningkatan warna $(45,56 \%)$, pertumbuhan total $(2,24 \mathrm{~g})$, laju pertumbuhan spesifik $(0,75 \% /$ hari) dan nilai $\mathrm{FCR}$ $(2,72)$ jika dibandingkan dengan perlakuan lainnya. 


\section{UCAPAN TERIMA KASIH}

Ucapan terimakasih kami sampaikan kepada pimpinan lembaga BBPPMPV Pertanian serta seluruh pihak yang telah membantu hingga penelitian ini selesai dilaksanakan.

\section{DAFTAR PUSTAKA}

Addini N, Pamungkas N A, Mulyadi, S. (2017). Peningkatan Kualitas Warna dan Pertumbuhan Ikan Albino Tiger Barb (Puntius tetrazona) dengan Pemberian Pakan yang Mengandung Tepung Udang Rebon. Berkala Perikanan Terubuk Vol 45(3), 44-56.

Afrianto dan Liviawaty. (1992). Pengendalian Hama dan Penyakit. Yogyakarta : Kanisius

Ahilan B, J. K. and F. N. (2013). Influence of Herbal Additives on the Growth and Disease Resistance of Goldfish, Carassius Auratus (Linnaeus). Journal of Aquaculture in the Tropics, 28(1-4), 77-84.

Arlyza,I.S.(2005). Isolasi Pigmen Biru Phycocyanin dari Mikroalga Spirulina platensis. Oseanologi dan Limnologi ISSN 0125-9830 No.38 : 79-92

Gupta, S. K., Jha, A. K., Pal, A. K., \& Venkateshwarlu, G. (2007). Use Of Natural Carotenoids For Pigmentation In Fishes. Natural Product Radiance, 6(1), 46-49.

Halver J E and Hardy R W. (2002). Fish Nutrition. Third Edition. Academic Press. California. $832 \mathrm{hlm}$

Hertrampf, J., E.P. Pascual. (1999). Handbook on Ingredients for Aquaculture Feeds. London: Kluwer Academic Publisher

Indarti, S., Muhaemin, M., \& Hudaidah, S. (2012). Modified Toca Colour Finder (MTCF) dan Kromatofor sebagai Penduga Tingkat Kecerahan Warna Ikan Komet (Carasius Auratus Auratus) yang Diberi Pakan Dengan Proporsi Tepung Kepala Udang (TKU) yang Berbeda. E-Jurnal Rekayasa dan Teknologi Budidaya Perairan, 1(1), 9-16.

Kalidupa, N., Kurnia, A., \& Nur, I. (2018). Studi Pemanfaatan Tepung Kulit Buah Naga Merah (Hylocereus polyrhizus) dalam Pakan Terhadap Pewarnaan Ikan Mas Koi (Cyprinus carpio L.) Media Akuatika, 3(1): 590-597.

Latscha, T. (1990). Carotenoids In Animals Nutrition: Their Nature And Significance In Animal Feeds. Roche Publication No. 2175, 110.

Lesmana, D. S. (2002). Kualitas Air untuk Ikan Hias Air Tawar. Penebar Swadaya, Jakarta

Malini, D. M., Dewi, T., \& Agustin, R. (2018). Pengaruh Penambahan Tepung Spirulina fusiformis pada Pakan Terhadap Tingkat Kecerahan Warna Ikan Koi (Cyprinus carpio L.). Jurnal Pro-Life, 5(2), 579-588. https://doi.org/10.1017/CBO9781107415324.004

Meilisza, N. (2018). Kualitas Warna, Pertumbuhan, dan Status Kesehatan Ikan Rainbow kurumoi (Melanotaenia parva) dengan Suplementasi Karotenoid dalam Pakan. Disertasi. Institut Pertanian Bogor.

Mortensen, A. (2006). Carotenoids And Other Pigments As Natural Colorants. Pure and Applied Chemistry, 78(8), 1477-1491. https://doi.org/10.1351/pac200678081477

Mudjiman. A. (1998). Makanan Ikan. Cet-XI. Penebar Swadaya Bogor

Nazhira S, Safrida. dan Sorong. Ali. (2017). Pengaruh Penambahan Tepung Labu 
Kuning (Cucurbita moschata D.) dalam Pakan Buatan Terhadap Kualitas Warna Ikan Maskoki (Carassius Auratus). Jurnal IImiah Mahasiswa Fakultas Keguruan dan IImu Pendidikan Unsyiah Vol 2, No 2. hlm 1-14

Noviantoro, A. Sudaryono, A dan Nugroho, R. A. (2017). Penambahan Tepung Bunga Marigold (Tegetes Erecta) pada Pakan Buatan Untuk Meningkatkan Kecerahan Warna Ikan Rainbow (Melanotaenia pearcox). Journal of Aquaculture Management and Technology, 4(4), 95-100.

O'Sullivan AM, O'Callaghan YC, O'Connor TP, O'Brien NM. (2011). The content and bioaccessiblity of carotenoids from selected commercially available health supplements. Proceedings of the Nutrition Society. 70 (OCE3). E62. doi:10.1017/S0029665111001029

Papilon U M dan Efendi M. (2017). Ikan Koi. Penebar Swadaya. Jakarta. 140 hal.

Prayogo, H H. Rostika, R. Nurruhwati, I. (2012). Pengkayaan Pakan yang Mengandung Maggot dengan Tepung Kepala Udang Sebagai Sumber Karotenoid Terhadap Penampilan Warna dan Pertumbuhan Benih Rainbow Kurumoi (Melanotaenia parva ). Jurnal Perikanan dan Kelautan. Vol.3(3), 201205.

Putriana N, Tjahjaningsih. W. dan Alamsjah. M. A. (2015). Pengaruh Penambahan Perasan Paprika Merah (Capsicum annuum) dalam Pakan Terhadap Tingkat Kecerahan Warna Ikan Koi (Cyprinus carpio L.). Jurnal Ilmiah Perikanan dan Kelautan Vol. 7 No. 2, 189-194.

Sartikawati. Junaidi, M. Damayanti, A. A. (2020). Efektivitas Penambahan Tepung Buah Labu Kuning pada Pakan Ikan Terhadap Peningkatan Kecerahan dan Pertumbuhan Ikan Badut (Amphipriion ocellaris). Jurnal Kelautan, 13(1), 24-35.

Subamia, I. W., Meilisza, N., \& Permana, A. (2013). Peningkatan Kualitas Warna Kuning dan Merah serta Pertumbuhan Benih Ikan Koi Melalui Pengayaan Tepung Kepala Udang Dalam Pakan. Jurnal Riset Akuakultur, 8(3), 429-438.

Sukarman. (2017). Kombinasi Astaxantin dan Ekstrak Bunga Marigold Dalam Pakan Untuk Meningkatkan Kualitas Warna Ikan Klown Amphiprion percula. Thesis. Institut Pertanian Bogor.

Tongsiri S, Mang-Amphan K, Peerapornpisal Y. (2010). Effect of Replacing Fishmeal with Spirulina on Growth, Carcass, Composition and Pigment of the Mekong Giant Catfish. Asian Journal of Agricultural Science. 2(3): 106-110.

Utomo, N.B.P. Carman O. Fitriyati, N. (2006). Pengaruh Penambahan Spirulina plantensis dengan Kadar Berbeda Pada Pakan Terhadap Tingkat Intensitas Warna Merah pada Ikan Koi Kohaku (Cyprinus carpio L). Jurnal Akuakultur Indonesia, 5(1): 1-4

Yaeni, T., Suminto, \& Yuniarti, T. (2017). Pemanfaatan Ekstrak Ubi Jalar (Ipomoea batatas var Ayumurasaki) Dalam Pakan Untuk Prforma Warna Tubuh, Pertubuhan dan Kelulushidupan Ikan Rainbow (Melanotaenia praecox). Journal of Aquaculture Management and Technology, 6(3), 293-302. 